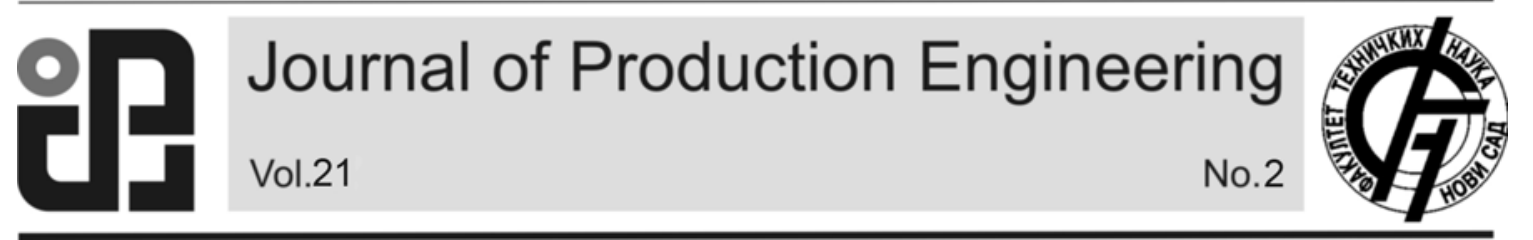

JPE (2018) Vol.21 (2)

Original Scientific Paper

Kostevšek, U., Drstvenšek, I., Balič, J., Moličnik, A., Vogrin, M., Stević, S., Brajlih, T.

\title{
INTERDISCIPLINARY COMMUNICATION IN ORTHOPEDIC SURGICAL PLANNING
}

Received: 03 September 2018 / Accepted: 09 December 2018

\begin{abstract}
The paper describes a process of $3 D$ planning of replacement of an acetabular component on a case of a defect with a huge bone loss estimated at level IIIa according to Paprosky. The planning was based on CT scans of the affected area and performed in interdisciplinary cooperation among surgeons and mechanical engineers. This cooperation combined surgical experiences and knowledge of surgeons with knowledge of engineers in using $3 D$ design tools and mechanical calculation. The cooperation resulted in a virtual $3 D$ plan and $3 D$ printed communication models that enabled flawless communication among the team members. This lead to a definition of optimal hip parameters (centre of rotation, inclination and version angles) in a virtual computer space. To transfer the virtually planned parameters and shapes into a real environment surgical equipment were custom made for the particular patient. These were surgical guides used to help the surgeon resect the femoral neck and to hold and guide the reamer while reshaping the acetabular cave. This way the centre of rotation, inclination and version angles were precisely transferred from a virtual computer space into the patient's hip. The implementation of the described procedure required some changes in the surgical process. To that purpose special documentation has been prepared that enables the surgeon to approve the surgical plan. Additionally, a user's guide was written that lists and describes all patient specific instruments and their use to enable a flawless surgical process.
\end{abstract}

Key words: $3 D$ pre-operative planning, selective laser sintering, hip, medical devices

Interdisciplinarna komunikacija u ortopedičnom hirurškom planiranju. Ovaj rad opisuje proces 3D planiranja zamene acetabularne komponente na slučaju defekata sa ogromnim gubitkom kostiju procenjenim na nivou IIIa prema Paproskiju. Planiranje je zasnovano na CT skenerima pogođenog područja $i$ obavljeno je u interdisciplinarnoj saradnji između hirurga i mašinskih inženjera. Ova saradnja kombinovala je hirurška iskustva $i$ znanja hirurga sa znanjem inženjera u korišćenju $3 D$ alata za dizajn i mehaničkih proračuna. Saradnja je rezultitala u virtuelne $3 D$ planove i $3 D$ štampane modele komunikacije koji omogućavaju besprekornu komunikaciju među članovima tima. Ovo dovodi do definisanja optimalnih parametara kukova (centar rotacije, uglova nagiba) u virtuelnom računarskom prostoru. Za prenošenje virtuelno planiranih parametara i oblika u stvarno okruženej, hirurška oprema je prilagođena za određenog pacijenta.To su bili hirurški vodiči koji su pomogli hirurgu da iseče butni vrat i drži $i$ vodi razvrtač da preoblikuje acetabularnu duplju. Na ovaj način centar rotacije, uglovi nagiba $i$ verzije su bili prebačeni iz virtuelnog prostora u kuk pacijenta. Implementacija opisane procedure zahtevala je neke promene u hirurškom procesu. U tu svrhu pripremljena je posebna dokumentacija koja omogućava hirurgu da odobri hirurški plan. Dodatno, napisano je upustvo za korisnike koje navodi i opisuje sve specifične instrumente pacijenta i njihovu upotrebu kako bi se omogućio besprekorni hirurški proces.

Ključne reči: $3 D$ pre-operativno planiranje, selektivno lasersko sinterovanje, kuk, medicinski uređaji.

\section{INTRODUCTION}

Aging society and unhealthy life style leads to a raising number of total hip replacement interventions. Since the primary THRs are performed on ever younger patients the number of revisions is in a constant raise too [1]. Due to severe bone defects a major intervention is needed when replacing a worn out or displaced hip endoprosthesis. Two dimensional pre-operative planning [2], which is due to a simple process still in general use has several disadvantages that often lead to longer surgical procedures [3], inaccurate positioning of endoprosthesis [4], additional bone loss [5], limb length discrepancy [6], longer rehabilitation and also in increased overall costs [7].

Pre-operative estimation of bone structure, its potential loss and optimal positioning of endoprosthesis is difficult or almost impossible to implement when using 2D data taken from conventional x-rays. Only three-dimensional, spatial data of a bone defect provide enough information for precise positioning of endoprostheses, accurate preoperative planning and flawless surgical process.

Y. Inaba et al. [8] investigated the efficacy of preoperative planning for implant placement with consideration of pelvic tilt in THA, and the accuracy of a CT based computer navigation for implant positioning. The research found that the Mean absolute error of combined anteversion between preoperative planning and post-operative measurement was $5^{\circ}$ with use of the CT based navigation.

A. J. Hughes et al [9] have conducted a 3D preoperative plan for surgery of two patients on the life size 3D models of the pelvis, which were manufactured from computed tomography scans by selective laser sintering. Acetabular reconstruction was planned, trialed, and 
managed efficiently with improved surgical precision and reduced complications. The accuracy and cost effectiveness of this technique were impressive and its increasing use should prove invaluable as a tool to aid clinical practice and education in the future.

Our research goes beyond the described investigation methods by providing the surgeons with patient specific resection guides that assure correct placement of the endoprostheses and less complications during the surgery.

\section{METHOD}

Conventional 2D pre-operative planning is performed on the anteroposterior (AP) pelvic radiography which directly provides the data about the inclination angle and the centre of hip's rotation. The version angle can only be calculated indirectly given that the lesser trochanter is visible in the radiograph and that its size can be reliably defined. This fact and a lack of reliable anatomical landmarks accessible during the surgery make 2D planning outdated and inappropriate for modern THA operations [10].

\subsection{Identifying anatomical landmarks on the bone structures}

Anatomical landmarks are intra-operational, easily accessible bone structures that are clearly visible on the radiographic images. These usually include medullary canal (shaft), the greater and lesser trochanter, the acetabular roof, saddle and the teardrop [10].

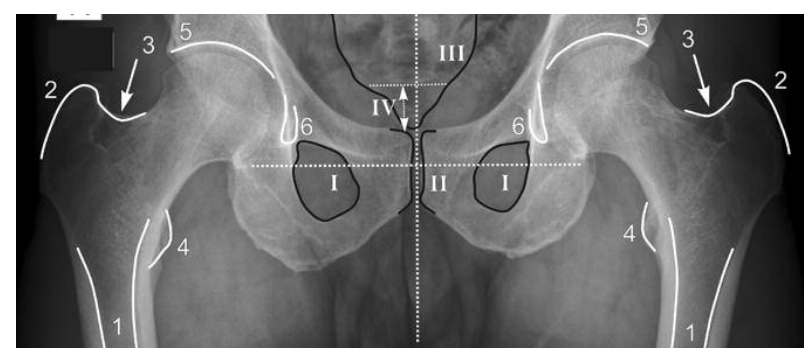

Fig. 1. Anatomical landmarks: 1. Femoral shaft; 2. Greater trochanter; 3. "Saddle"; 4. Lesser trochanter; 5. Acetabular roof and 6. Teardrop

The problem of anatomical landmarks is that most of them are only visible on the radiographic images (some even as a result of overlapping bone structures) but most of them cannot be seen "in vivo" during the surgery.

\subsection{Identifying mechanical references}

Mechanical references are distances among different landmarks that define the functionality of the hip joint.

After the THA operation, the hip movement has to be restored into its anatomical state. This can only be assured by a proper definition of mechanical references, e.g. original acetabular and femoral rotation center, the femoral and acetabular offset and the leg length.

The measurements shown in Fig. 2 are unreliable because they depend on the circumstances of the 2D radiograph acquisition its magnification factor and the influence of the version angles unidentifiable in the 2D plane of the radiograph [10]. In a f3D space obtained from the $\mathrm{CT}$, datasets all the measurements are done directly and their precision only depends on the accuracy of the CT scanner, which is always precise enough for the surgical purposes as has been shown in this research.

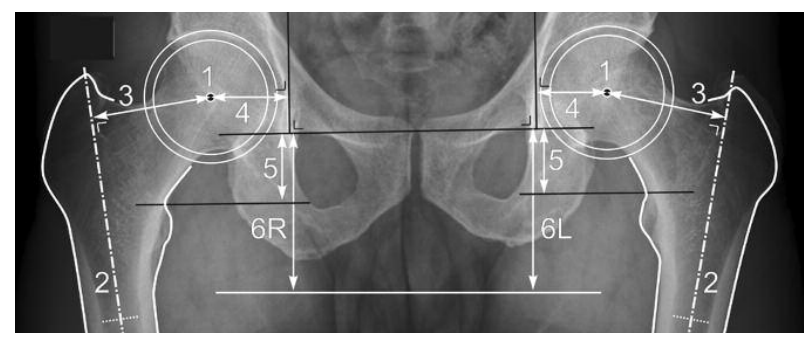

Fig. 2. Mechanical references: 1. Hip rotation centre; 2. Longitudinal axis of the proximal femur; 3. Femoral offset; 4. Acetabular offset; 5. Hip length. ("Leg length discrepancy" - distances between the $6 \mathrm{~L}$ and $6 \mathrm{R}$ )

\subsection{Optimizing implant positioning to restore hip biomechanics}

Positioning of endoprostheses in the 2D plane of the radiograph relies on different templates provided by the implant manufacturer. By placing the template over the radiograph the surgeon defines the direction, the centre of rotation, position and size of the endoprosthesis [10]. The accuracy of this process depends on the magnification of the radiograph. In the $3 \mathrm{D}$ space the surgeon can use 3D models of implants that can be virtually placed into the femur thus simulating the real outcome of the THA. Additionally, the size of the defect, bone density and its quality can be foreseen in the 3D model. 3D planning includes, a full overview of the shape of the bone structures and size of the defect.

\subsection{D pre-operative planning}

To overcome the obstacles of 2D surgical planning we have combined its benefits with the possibilities of the $3 \mathrm{D}$ space. This is obtained by the reconstruction of bone structures from the $\mathrm{CT}$ scans. The reconstruction starts by segmentation of DICOM data and transformation of the segmented dataset into a 3D file, usually in STL format.

Prior to the 3D surgical planning process a coordinate system has to be defined, which corresponds to the established surgical practice. According to the method of the research Baauw M. et al. [11] we defined the Cartesian coordinate system of three planes (sagittal coronal and transversal) using 3D landmarks found in the STL model. The 3D planning consist of two phases. In the first phase we defined the anatomical parameters of the hip joint and in the second phase we have modelled the devices to transfer the defined parameters into the patient's body.

The anatomical parameters are version and inclination angles and the center of rotation. In the 3D space they can be precisely defined by the use of geometrical primitives and Boolean operators provided by the CAD software package. By placing the primitives into the virtual bone structure we have measured and calculated the anatomical parameters of the hip with the accuracy and reliability not possible in 
the 2D planning process. By Boolean operators we have subtracted the bone structure from the geometrical primitives in order to model the devices that can be produced in the reality. These devices were used during the surgery as patient specific resection guides that helped the surgeon to maintain the calculated anatomic parameters in the operational space. Resection guide is intended solely for the inter-operational use to transfer the references of the virtual coordinate system into the patient's body, thus facilitating the achievement of planned parameters (CR, INC AV).

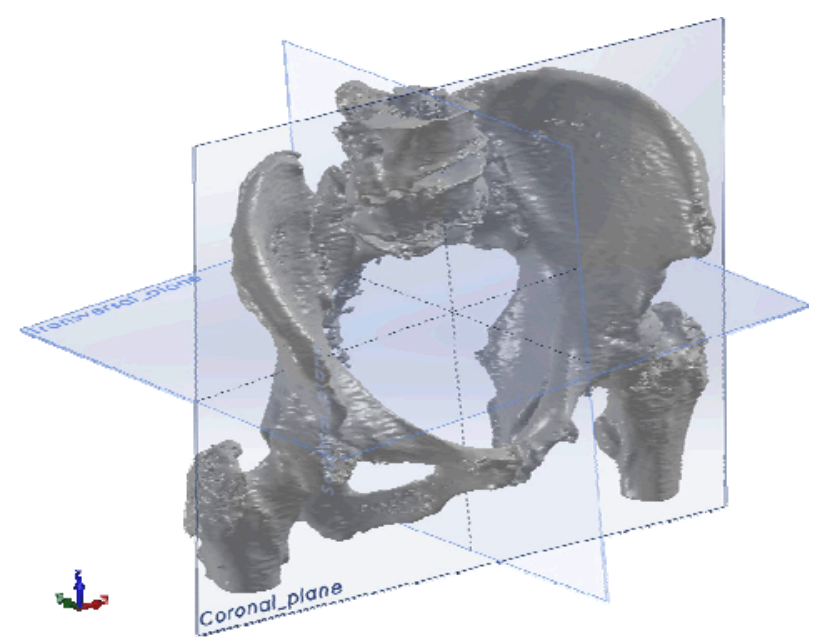

Fig. 3. Individual Cartesian coordinate system of three planes (sagittal coronal and transversal).

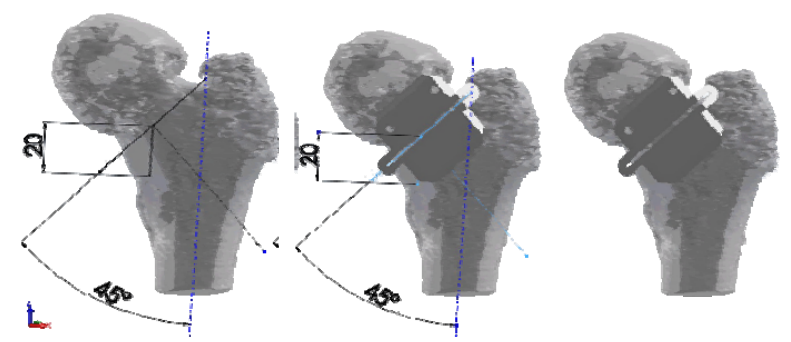

Fig. 4. Individual medical devices for the femoral resection.

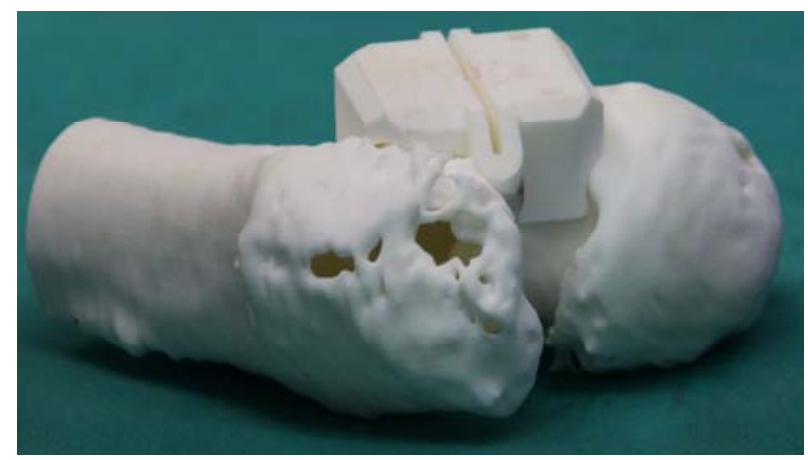

Fig. 5. Guides for the femoral resection

\section{RESULTS}

The described method has been clinically tested on 5 patients. We have obtained the informed consent. For all of them the above described method has been used. In the continuation we are presenting the results of postoperative CT analysis of the patient that suffered from primary osteoarthritis type IIA according to the Paprosky classification system.

Table 1 shows the difference between the planned and post-operative position (Centre of Rotation) of the implant.

\begin{tabular}{|c|c|c|c|}
\hline $\begin{array}{c}\text { Transversal } \\
\text { plane }\end{array}$ & Planned & $\begin{array}{c}\text { Post- } \\
\text { operative }\end{array}$ & Difference \\
\hline CR_FE & 95,82 & 95,77 & 0,05 \\
\hline CE_AC & 95,82 & 95,50 & 0,32 \\
\hline $\begin{array}{c}\text { Sagittal } \\
\text { plane }\end{array}$ & Planned & $\begin{array}{c}\text { Post- } \\
\text { operative }\end{array}$ & Difference \\
\hline CR_FE & 46,87 & 46,28 & 0,59 \\
\hline CE_AC & 46,87 & 46,32 & 0,55 \\
\hline $\begin{array}{c}\text { Coronal } \\
\text { plane }\end{array}$ & Planned & $\begin{array}{c}\text { Post- } \\
\text { operative }\end{array}$ & Difference \\
\hline CR_FE & 1,91 & 2,97 & 1,06 \\
\hline CE_AC & 1,91 & 3,16 & 1,25 \\
\hline
\end{tabular}

Table 1. Data of planned and post-operative centers of rotation in the $\mathrm{mm}$

The results in Table 1 show that the largest deviation between the planned and actual position occurs in the coronal plain $(1,25 \mathrm{~mm})$. The absolute spatial difference is $1.40 \mathrm{~mm}$. The differences are at the border of the CT scanner's accuracy and therefore negligible.

Table 2 represent the differences in the orientation of the implanted endoprostheses (INC and AV).

\begin{tabular}{|l|l|l|l|}
\hline Inclination & Planned & $\begin{array}{l}\text { Post- } \\
\text { operative }\end{array}$ & Difference \\
\hline INC_FE & $135^{\circ}$ & $132,73^{\circ}$ & $2,27^{\circ}$ \\
\hline INC_AC & $40,75^{\circ}$ & $41,53^{\circ}$ & $0,78^{\circ}$ \\
\hline
\end{tabular}

Table 2. Comparison of planned and post-operative angles of inclination (INC)

\begin{tabular}{|c|c|c|c|}
\hline Anteversion & Planned & $\begin{array}{c}\text { Post- } \\
\text { operative }\end{array}$ & Difference \\
\hline AV_FE & $15,13^{\circ}$ & $13,98^{\circ}$ & $1,15^{\circ}$ \\
\hline AV_AC & $26,73^{\circ}$ & $24,77^{\circ}$ & $1,96^{\circ}$ \\
\hline
\end{tabular}

Table 3. Comparison of planned and post-operative angles of anteversion (AV)

The difference between planned and post-operative inclination of the femur is relatively high as compared to other orientation angles $\left(2,27^{\circ}\right)$. This is due to an unreliable definition of the femoral anteversion that can only be defined according to the direction of the condyles in the knee joint, which are not visible in the CT of the pelvis area. Therefore, the femoral anteversion has been measured against the position of the pelvis. This measurement depends on the position of the leg during scanning. Even though the difference of the femoral anteversion is almost negligible if compared to the results of the conventional, 2D planning. Much less difference occurred between planned and postoperative inclination of the acetabulum, which measures $0,78^{\circ}$. 


\section{CONCLUSION}

One of the main challenges in hip arthroplasty is correct determination of kinematic relations in the hip joints. Accurate insertion of the hip endoprosthesis according to a pre-operationally planned position and orientation is still a problem. Conventional determination of size and position of the prosthesis based on 2D radiographic image often leads to intraoperational complications, because of the lack of data in the $2 \mathrm{D}$ radiographic image and because of the missing "in vivo" references that would enable the surgeon to position the implant exactly into the planned position. The surgeons are trying to compensate the disadvantages of $2 \mathrm{D}$ planning with their experience. An increase in the requirements for revision surgery suggests that more attention should be paid to the exact restoration of the hip biomechanics. The 3D reconstruction of pelvic bones from the CT scanning data, and $3 \mathrm{D}$ pre-operational planning simplifies the operational process and makes it more accurate. The accuracy of the implant's insertion is ensured by patient specific resection guides that fit perfectly to the morphology of the patient's pelvic bones, thus assuring the planned positioning and functioning of the prostheses.

\section{REFERENCES}

[1] Levašič V., Pišot V., Milošev I.: Arthroplasty Register of the Valdoltra Orthopaedic Hospital and implant retrieval program, Article in Zdravniški vestnik 78, Ljubljana, 2009

[2] Huppertz A., Radmer S., Wagner M., Roessler T., Hamm B., Sparmann M.: Computed tomography for preoperative planning in total hip arthroplasty: what radiologists need to know. Skeletal Radiol 43:1041-1051 DOI 10.1007/s00256-014-1853-2, (2014)

[3] Blackley HR,: Planning and management of the difficult primary hip replacement: preoperative planning and technical considerations. Instr Course Lect: 49, 2000

[4] McAuley JP,: Preoperative planning to prevent dislocation of the hip, Orthop Clin North Am;32:4., 2001
[5] Haddad FS,: Femoral bone loss in total hip arthroplasty: classification and preoperative planning. Instr Course Lect :49, 2000

[6] Suh KT,: Comparison of preoperative templating with postoperative assessment in cementless total hip arthroplasty, Acta Orthop Scand ;75:1, 2004

[7] Goldstein WM,: Leg length inequality in total hip arthroplasty. Orthopedics; 28(9 Suppl), 2005

[8] Inaba Y., Kobayashi N., Suzuki H., Ike H., Kubota S., Saito T,: Preoperative planning for implant placement with consideration of pelvic tilt in total hip arthroplasty: postoperative efficacy evaluation, BMC Musculoskeletal Disorders, 17:280, DOI 10.1186/s12891-016-1120-x, 2016

[9] Hughes A. J., DeBuitleir C., Soden P., O’Donnchadha B., Tansey A., Abdulkarim A., McMahon C., Hurson C. J.: 3D Printing Aids Acetabular Reconstruction in Complex Revision Hip Arthroplasty Hindawi Publishing Corporation, Advances in Orthopedics, Volume, Article ID 8925050, 7 pages, 2017

[10] Scheerlinck T.,: Primary hip arthroplasty templating on standard radiographs A stepwise approach. Acta Orthop. Belg., 76, 432-442, 2010.

[11] Baauw M., Hellemondt van G.G., Hooff van M.L., Spruit M.,: The accuracy of positioning of a custommade implant within a large acetabular defect at revision arthroplasty of the hip. Bone Joint J; VOL.97-B: No.6, 780-785, 2015

Authors: Urška Kostevšek MSc, prof. dr. Jože Balič, prof. dr. Igor Drstvenšek, Assis. dr. Tomaž Brajlih, Faculty of Mechanical Engineering, University of Maribor, Slovenia

Assis. dr. Andrej Moličnik, prof. dr. Matjaž Vogrin, University Medical Centre Maribor. Slovenia

dr. Snezana Stević, Medical Faculty, University of Priština-Kosovska Mitrovica. Serbia

E-mail: urska.kostevsek@um.si igor.drstvensek@um.si joze.balic@um.si andrej.molicnik@gmail.com matjaz.vogrin@um.si s.hadzistevic@med.pr.ac.rs tomaz.brajlih@um.si 